\title{
HAZARDS IN THE CARIBBEAN: THE HISTORY OF MAGMA CHAMBERS, ERUPTIONS, LANDSLIDES, STREAMS, AND FUMEROLES IN DOMINICA
}

HOLLI FREY, Union College

AMANDA SCHMIDT, Oberlin College

EROUSCILLA JOSEPH, University of West Indies Seismic Research Center

LAURA WATERS, Sonoma State University

\section{INTRODUCTION}

The Caribbean has been the site of significant historic volcanism, from the ongoing eruptions in Monserrat to the devesating eruptions of Mt. Pelee, Martinique and Soufriere, St. Vincent in 1902, in which 32,000 people perished. However, the island with the most volcanic hazard risk is Dominica, which experienced the largest explosive eruption in the Caribbean in the last $200 \mathrm{kyr}\left(\sim 58 \mathrm{~km}^{3}\right)$ and features nine potentially active volcanic centers that are Pleistocene or younger in age (Carey and Sigurdsson, 1980; Lindsay et al., 2005), and had phreatic eruptions in the Valley of Desolation in 1880 and 1997. The landscape of Dominica has been shaped by its volcanic history and tropical climate, as evidenced by its heavily weathered terrains and preponderance of landslides. It is characterized by lava domes and extensive block and ash flows and explosive deposits, as well as numerous geothermal areas with fumeroles and steam vents. Multiple shallow seismic swarms since the late 1990s (Lindsay et al., 2003, Smith et al., 2013) suggest the region may be undergoing a periodic of volcanic unrest.

Today, Dominica is known as the Nature Island of the Caribbean and significant efforts have been made to increase tourism. There are numerous eco-tourism sites and the Waitukubuli National Trail, an islandwide $185 \mathrm{~km}$ hiking trail, was recently completed. The tourism sites feature active geothermal areas, with fumeroles and steam vents, as well as older lava flows and explosive deposits of pumice and ash. Dominica's volcanic unrest has also drawn the attention of the scientific community. Increased levels of volcanoseismic activity in the northern and southern portions of the island since the late 1990s prompted a reassement of the geologic hazards of Dominica (Lindsay et al., 2003) and targeted GPS monitoring campaigns. One volcano in northern Dominca, Morne aux Diables (MAD) was recently studied by VUELCO (Volcanic unrest in Europe and Latin America: Phenomenology, eruption precursors, hazard forecast, and risk mitigation), a consortium of scientists seeking an understanding of the processes behind volcanic unrest and the ability to forecast its outcome. In Dominica, VUELCO aimed to use existing seismic, GPS, and geochemical data from geothermal areas around MAD to better model and understand geothermal systems as a potential precursor to eruptive activity. A VUELCO workshop was held in Dominica in May 2015 (attended by Frey and Joseph), in which researchers presented their preliminary findings and participated in an eruption crisis simulation exercise with local government officials and disaster management organizations. The consensus was that more primary research and baseline monitoring would be valuable and help with future risk assessments.

\section{GEOLOGIC SETTING}

The Lesser Antilles arc in the eastern Caribbean is approximately $850 \mathrm{~km}$ in length and extends from St. Kitts in the north to Grenada in the south with a total of 11 volcanic islands (Fig. 1). The volcanism is caused by the westward subduction of the $90 \mathrm{Ma}$ 


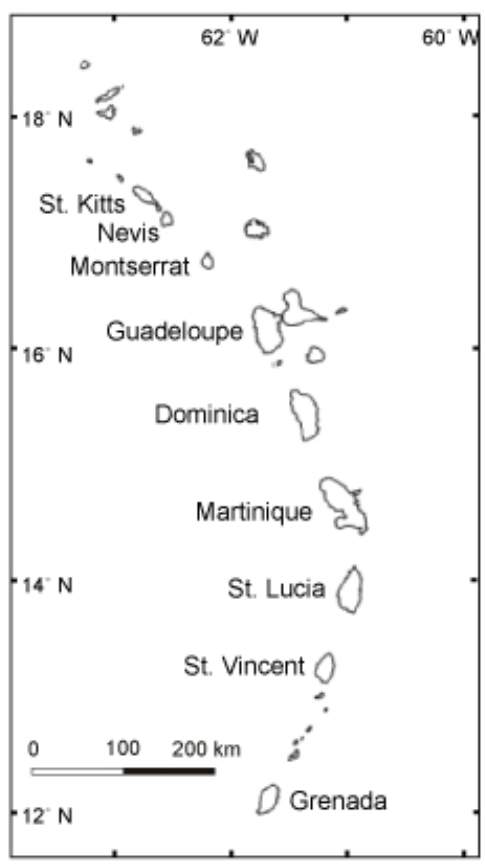

Figure 1. Geographic map of the Lesser Antilles volcanic arc.

North American Plate under the Caribbean Plate. The Lesser Antilles island arc is segmented, with the north trending at $330^{\circ}$ and the south trending at $020^{\circ}$ (Arculus and Wills, 1980; Wadge and Shepherd, 1984). The slab dip angle is approximately $50-60^{\circ}$ in the north and $60-90^{\circ}$ in the south. The northern volcanic islands (north of Martinique) have high levels of seismicity and a subduction rate of $2.0 \mathrm{~cm} / \mathrm{yr}$ (DeMets et al., 2000) whereas the southern volcanic islands do not have a history of large earthquakes and the rate of subduction is slower, only $1.8 \mathrm{~cm} / \mathrm{yr}$ (DeMets et al., 2000). Dominica is located in the central portion of the arc, where these segments converge, with a $45-50^{\circ}$ dipping Wadati-Benioff zone approximately 160-180 $\mathrm{km}$ beneath the volcanic front (Lindsay et al., 2005b). The physical segmentation and differences in subduction rates may drive the voluminous volcanism observed on Dominica. Dominica is considered to be the most volcanically productive and hazardous island in the arc, with nine potentially active volcanic centers, the majority of which are located within $10 \mathrm{~km}$ of the capital of Roseau, located in the southern portion of the island (Lindsay et al., 2005b).

Dominica is a $750 \mathrm{~km}^{2}$ island (Fig. 2) of rugged topography and pristine rainforest which features nine volcanic centers that are $<2.6 \mathrm{Ma}$ in age (Lindsay et al., 2005a). Dominica's coastlines and interior val- leys abound with thick ( $>20 \mathrm{~m})$ ignimbrite deposits, composed of pumice clasts, rock fragments, and ash from solidified pyroclastic flows. Some ignimbrites are welded and up to $200 \mathrm{~m}$ thick in valleys in central Dominica, with thickness generally decreasing towards the coast. Ash from these eruptions has blanketed nearby Caribbean islands and the eastern Caribbean Sea. Although only $\sim 3 \mathrm{~km}^{3}$ of debris from the explosive eruptions remains in the central valleys of Dominica today, the distribution and thickness of ash found in the drill cores of oceanic material in the Caribbean Sea allowed for an estimation of the material that erupted in the past. More than $58 \mathrm{~km}^{3}$ of material was erupted from Dominica, making it the largest explosive eruption in the Caribbean in the last $200 \mathrm{kyr}$ (Sigurdsson, 1972; Carey and Sigurdsson, 1980).

There have been no documented explosive eruptions of large magnitude in Dominica in the last $20 \mathrm{kyr}$. The most recent activity involving magma was a lava

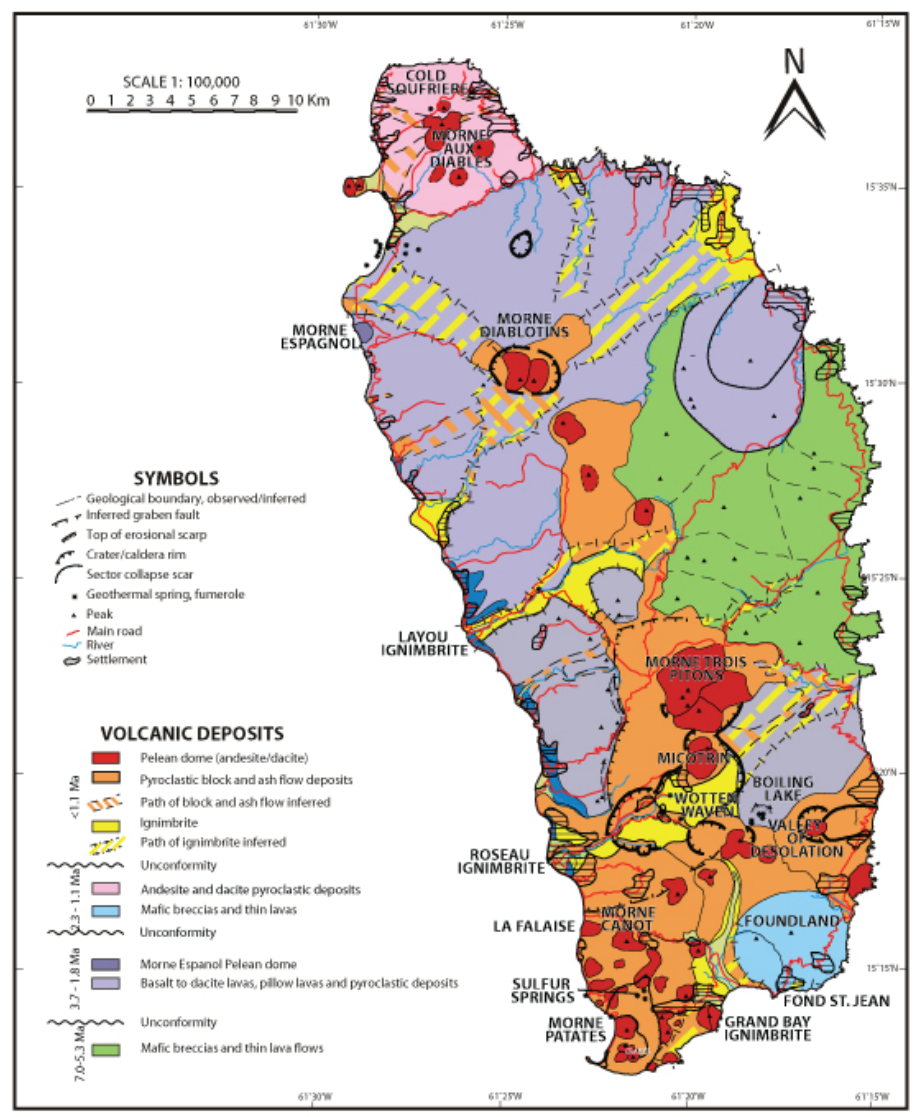

Figure 2. Geologic map of Dominica adapted from Smith et al. (2013). 
dome collapse. Lava domes form when degassed and now very viscous magma reaches the surface. They often post-date explosive eruptions, in which most of the volatiles $\left(\mathrm{H}_{2} \mathrm{O}, \mathrm{CO}_{2}, \mathrm{H}_{2} \mathrm{~S}\right)$ are released. Lava dome growth can occur over decades with the slow extrusion of magma building a steep-sided dome. Periodically, these domes become over-steepened and collapse, jettisoning large angular blocks of lava downslope to form block and ash deposits. There are numerous block and ash deposits found throughout the island. The youngest block and ash deposit is thought to be in southern Dominica, which has an abundance of lava domes. Arcaheological investigations in the late 1970s unearthed clay pots beneath an ash horizon near the village of Soufrierre. Charcoal within the ash was dated at $450 \pm 90$ years B.P. (Roobol et al., 1983).

Dominica's most recent volcanic activity was several explosions of steam and ash violently ejected from hydrothermal vents. Phreatic eruptions ocurred in the Valley of Desolation in 1880 and 1997, covering an area $<1 \mathrm{~km}^{2}$ with a thin $(\sim 2 \mathrm{~cm})$ layer of ash (Lindsay et al., 2005b). The Valley of Desolation is an active hydrothermal area and popular hiking destination of tourists. The name is likely derived from the stark landscape, devoid of vegetation from past steam explosions. The smell of rotten eggs from the release of sulphur dioxide permeates the valley and sulphur crystals ring many of the fumeroles or steam vents that hiss as they release gas. Hot, acidic mudpots up to $2 \mathrm{~m}$ in diameter bubble, gurgle and pop, releasing carbon dioxide. At the far end of the valley lies Boiling Lake, a $75 \mathrm{~m}$ volcanic lake that is is typically very hot $\left(80-90{ }^{\circ} \mathrm{C}\right)$ and acidic ( $\mathrm{pH}$ of 3-5). The Valley of Desolation and Boiling Lake exist bcause magma is present beneath the surface, heating the groundwater and releasing volcanic gasses like $\mathrm{CO}_{2}$ and $\mathrm{SO}_{2}$.

In addition to the older volcanic deposits and active hydrothermal areas, Dominica's volcanic present is recorded by earthquake swarms. The earthquakes are typically shallow $(<5 \mathrm{~km})$ and of fairly low magnitude $(<4.0)$, often ocurring in rapid succession or swarms. Often an increase in the frequency of seismicity or the magnitude of earthquakes is one of the first indicators that a volcano may become active again. Since monitoring in Dominica began in 1952 by the University of the West Indies Seismic Research Center
(UWI-SRC), there have been several periods of more intense seismicity, particularly in the last two decades in northern and southern Dominica. In 2003, >1000 earthquakes were recorded in northern Dominica, all of which were under magnitude 3.5. The same region experienced another period of increased seismicity from 2009-2012. On October 21, 2009, twenty-one earthquakes were reported overnight, and two were felt in the town Portsmouth, damaging local buildings. The earthquake swarms in southern Dominica occurred in the mid-late 1990s. None of these periods of heightened seismicity were a precursor to a volcanic eruption and the earthquake tremors returned to background levels. In the last few years, there have been two clusters of low magnitude shallow earthquakes, one in Sulphur Springs, an active geothermal region, and one in Salisbury, a coastal village built on $\sim 80 \mathrm{ka}$ ignimbrite deposits.

\section{STUDENT PROJECTS}

The Dominica Keck project is the inaugural Frontier project of the Keck Consortium. The goal of a Frontier project is to bring together a larger group of students and faculty to approach a problem or geologic setting from a multi-disciplinary perspective. The rugged volcanic landscape of Dominica afforded us the opportunity to investigate a relatively active volcanic system that has not been well studied. A better characterization of the geologic history and current conditions on Dominica will add critical knowledge that may help us better understand volcanic unrest and the threat of eruptions and other natural disasters, such as landslides induced by hurricanes. The work presented herein pre-dates by two months the devastating Cat. V Hurricane Maria, which destroyed much of the island in September, 2017. However, Schmidt returned to Dominica in January, 2018 to collect post-Maria sediment from the rivers.

Through our two-week field season in Dominica and subsequent analytical work in various labs, we explore various petrologic and volcanic questions, the interaction of hydrothermal gasses with fluids, and how a volcanic landscape erodes in a tropical climate. The project builds on previous work by Frey and students, funded by National Geographic, and by Joseph and the on-going monitoring efforts of the UWI-SRC. This previous work has been presented at 
AGU, GSA, NE GSA, and IAVCEI and the focus of more than a dozen senior theses. Schmidt received a RAPID NSF grant following Hurricane Maria to study the effects of the storms on the landscape, so she will be continuing work initiated on this project. Fifteen students from fourteen institutions completed projects and initial results were presented at AGU in December, 2017. Summaries of their findings are presented below.

\section{Petrology (Frey and Waters)}

Despite its hazard potential and number of volcanoes, Dominica's volcanic history and geology have been somewhat poorly studied, likely owing to the country's rugged terrain, humid climate, and lack of easily accessible outcrop. Detailed petrologic studies of the lava domes have been restricted to the southern Plat Pays volcanic complex (Wills, 1974; Roobol et al., 1983; Lindsay et al., 2003; Lindsay et al., 2005; Gurenko et al., 2005; Halama et al., 2006). Smith et al. (2013) presented an island-wide reconnaissance of the bulk and mineral chemistry of many lava domes and flows, as well as the explosive deposits found throughout the island. More detailed characterizations have been published for the Grand Savanne ignimbrite (>22 ka; Sparks et al., 1980), Roseau ignimbrite ( 2846 ka; Sigurdsson, 1972; Carey and Sigurdsson, 1980; Howe et al., 2014; Boudon et al., 2017) and Grand Bay ignimbrite ( 39 ka; Lindsay et al., 2005).

The petrology student projects span an array of topics, but all took advantage of scanning electron microscopy to image minerals and textures, as well as to do quantitative analysis, which allowed for the quantification of intensive variables like temperature (Ghiorso and Evans, 2008) and water content (Waters and Lange, 2015).

Jessie Bersson (Whitman College) evaluated whether changing intensive variables (e.g., pressure, temperature) and/or compositional variables (e.g., water contents) were responsible for the oscillation between explosive and effusive volcanism at Wotten Waven caldera by conducting a detailed petrologic study on the ignimbrites and lava domes. Plagioclase, ilmenite and magnetite were analyzed in several pumice clasts from the Roseau Ignimbrite and samples of lava from a fresh rock fall from the Micotrin lava dome using electron dispersion spectroscopy (Union College) and the electron microprobe (University of California, Davis). Compositions of mineral phases are incorporated into a geo-thermometer and hygrometer to determine the temperatures and water contents in equilibrium with the melts at the time of crystallization. The results reveal that the Roseau ignimbrite had pre-eruptive conditions that were colder and more hydrous than the Micotrin lava dome. These results broadly inform how the caldera cycle of volcanism proceeds in Dominica; the first phase is defined by a colder, hydrous explosive eruption, which is followed by a second, hotter, extrusive phase that results in a lava dome.

Justin Casaus (Sonoma State University) compared the pre-eruptive intensive variables and plagioclase compositions between the Layou ignimbrite and the Morne Trois Piton lava dome forming eruption to understand what caused a changing in eruptive style. Fe-Ti oxides and plagioclase compositions were measured using the electron dispersion spectroscopy (Union College) and the electron microprobe (University of California, Davis). Fe-Ti oxide compositions were incorporated into a model thermometer to determine pre-eruptive temperatures. These temperatures and plagioclase compositions were incorporated into a model hygrometer to determine pre-eruptive water contents. Hygrometry results reveal that plagioclase crystals in both the ignimbrite and the lava dome record a continuous range of water contents, and that crystallization in the ignimbrite began at higher water contents (i.e., pressures) than the dome. If the dome is derived from the same magmatic source as the ignimbrite, then some mechanism to induce heating is required. The dome lavas notably contain mafic enclaves, and comparison with other studies in the literature suggests these enclaves were the source of additional heat, which could have caused the extrusion of the lava dome.

Nolan Ebner (Macalaster College) mapped a 15 $\mathrm{m}$-thick ignimbrite sequence near Fond St. Jean in southern Dominica and compared the stratigraphy, geochemistry, mineralogy, and intensive variables to the nearby Grand Bay Ignimbrite, a hypothesized more proximal unit in an ignimbrite sequence (Lindsay et al., 2005). Unlike the unconsolidated ignimbrite 
units of Grand Bay, Fond St. Jean exhibited several sub-meter to meter scale graded layers with varying proportions and sizes of pumice and lithic clasts, as well as abundance of ash. The bulk chemistry of the units was distinctive, with pumice clasts from Grand Bay typically exhibiting a homogeneous chemistry, whereas pumice clasts from Fond St. Jean displayed significant variability, and lacked linear trends which would reflect a genetic relationship due to fractional crystallization. REE trends between the units are not parallel, also suggesting different sources. The mineral assemblages of the units are comparable, but Fond St. Jean is less crystal-rich and contains $\sim 4 \%$ amphibole, which is absent in Grand Bay. Mineral compositions and zoning of plagioclase, pyroxenes, and oxides, were comparable, leading to broadly similar calculated intensive variables. However, the stratigraphy and bulk chemistry clearly demonstrate the lack of a genetic relationship between the deposits, so the Fond St. Jean Ignimbrite must now be considered a distinct unit.

Sarah Hickernall (Union College) investigated enclaves in the andesitic Morne Micotrin lava dome, which post-dates the explosive Roseau Ignimbrite. Enclaves were basaltic andesite and classified as coarse- or fine-grained. Bulk rock geochemistry showed linear trends for some elements and chondritenormalized patterns were parallel for the host and coarse-grained enclaves. However, several elements did not show linear trends and REE in the fine-grained enclaves were depleted, suggesting fractional crystallization cannot explain the variation. Open system behavior is further supported by variable abundances and compositional analyses of mineral phases (plag $+\mathrm{cpx}$ + opx $+\mathrm{qtz}+$ ox). Plagioclase ranged in composition from $\mathrm{An}_{45-94}$, with normal and reverse zoning. Plagioclase rims within the enclaves contained significant potassium, suggesting a unique crystallization history. Pyroxene in the enclaves typically displayed reverse zoning and cpx was found primarily only as rims on opx in the coarse-grained enclaves. Oxides within the enclaves exhibited significant exsolution and twooxide thermometry yielded two sets of temperatures, $\sim 50^{\circ} \mathrm{C}$ hotter and cooler than the host andesite. The enclaves confirm open system behavior and suggest that mafic recharge may trigger eruptions on Dominica, similar to nearby Montserrat.
Taryn Isenburg (Mt. Holyoke College) mapped a $35 \mathrm{~m}$ sequence of massive basaltic flows, scoria, lapilli, and ash lenses, associated with a previously undescribed cinder cone within the Foundland Center in southern Dominica near Fond St. Jean. All units contain plagioclase + olivine + clinopyroxene + orthopyroxene + titanomagnetite + spinel and have similar mineral compositions. Plagioclase are typically normally zoned with An-rich cores and more sodic rims. Olivine in most units ranges in composition from Fo55-70. With respect to whole-rock chemistry, the Fond St. Jean basalts are the most primitive on the island (48-52 wt $\% \mathrm{SiO}_{2}$ ), with relatively high $\mathrm{Al}_{2} \mathrm{O}_{3}$ (20-23 wt\%) and low $\mathrm{MgO}(4-5 \mathrm{wt} \%)$. Within the section, there is no systematic compositional variation. Trace and REE abundances are typical of oceanic island arcs, with a slight affinity for MORBs. However, some trace element ratios such as $\mathrm{Th} / \mathrm{La}$ indicate the Fond St. Jean basalts were contaminated by sediments and are not derived directly from uncontaminated mantle. Therefore, it is difficult to model these basalts as a parental magma that underwent crystal fractionation to produce the voluminous intermediate material on Dominica.

Abadie Ludlam (Union College) studied the breakdown of amphibole in four andesitic-dacitic lava domes from across the island. Due to its limited stability, amphibole undergoes reactions, attributed to a decrease in pressure and/or an increase in temperature $\left(>950{ }^{\circ} \mathrm{C}\right)$. Thickness of reaction rims of amphiboles has been used a proxy for ascent rate in some volcanic systems like Mount St. Helens. In Dominica, two lava domes (La Falaise and Canot) had amphibole phenocrysts that were complete replaced by a mixture of plagioclase, orthopyroxene, clinopyroxene, and Fe-Ti oxides. Four different textures were identified in these samples, with variable crystal sizes, zoning, and degree of disaggregation. Amphibole in Morne Patates had thin $(10-50 \mu \mathrm{m})$ reaction rims, composed of similar mineralogy, but devoid of clinopyroxene. Amphibole in Morne Espagnole featured amphibole with slightly thicker reaction rims, with inner portions containing clinopyroxene, but lacking in the outermost rim. There were no compositional, chronological, or geographical constraints on the observed textures. The different textures were attributed to decompression (completely reacted crystals) and heating (thin, cpx- 
absent rims), based on comparison of textures with the literature and temperatures obtained by two-oxide thermometry.

\section{Clarissa Itzel Villegas Smith (Carleton College)} analyzed the hydrothermal alteration of andesitic clasts from three different geothermal areas on the island: Cold Soufriere, Valley of Desolation, and Sulfur Springs. The hydrothermal waters of Dominica are acid-sulphate in composition and the degree of hydrothermal alteration appears to be a function of the temperature and amount of surface water of the particular geothermal area. XRD analysis of clast rinds and Rietveld analysis of the XRD spectra identified fifteen different minerals, including silica polymorphs, hematite, alunite minerals, sulfates, sulfides, and feldspars. Silica polymorphs are dominant with about $70 \%$ of the samples containing cristobalite, likely replacing plagioclase, as observed in elemental maps of the clast-rind boundary. The minerals present are typical of rock alteration by low temperature $\left(<300{ }^{\circ} \mathrm{C}\right)$ acidsulfate fluids, suggesting that the alteration is a result of mixing of shallow sulfate water and gasses. One sample from the Cold Soufriere included a finegrained mix of iron, sulfur, and titanium, which is a rare combination of elements, previously described in Martian soils.

Katie Von Sydow (Cal State San Bernadino) conducted a geochemical and petrographic study on mafic lavas from Foundland in southern Dominica. The most voluminous eruptions on Dominica are the intermediate $\left(\sim 60 \mathrm{wt} \% \mathrm{SiO}_{2}\right)$ lava domes and ignimbrites, and eruptions of basalt occur in relatively low frequency in most locations across the island. Foundland, a relatively remote region in southeastern Dominica, and proto-Morne aux Diables (northern Dominica), however, feature basaltic volcanism in relatively great abundance. This study aims to compare new samples from Foundland to those from proto-Morne aux Diables (Smith et al., 2013) on the basis of whole rock geochemistry, modal abundances, and compositions of phenocrysts to determine if the mafic lavas are likely from the same source. Major element concentrations were determined using XRF analyses at Pomona College and reveal that the mafic lavas in Foundland span a range in composition from low magnesium, high aluminum basalts to andesite. All lavas contained a similar phenocryst assemblage consisting of plagioclase + olivine + clinopyroxene + orthopyroxene + Fe-Ti oxides (mostly magnetite). In a single sample, hornblende was observed. Foundland lavas have many commonalities with the proto-Morne aux Diables basalts, suggesting that they could be derived from a similar source; however, the phase assemblage in the Foundland lavas requires them to evolve to colder, more hydrous, and more crystalline conditions.

\section{Fluids and Gasses (Joseph)}

Volcanic gases and hydrothermal waters were sampled from five (5) hydrothermal areas across the island (Valley of Desolation, Sulphur Spring, Watten Waven, Galion and Penville Cold Soufriere; Fig. 2) to determine temporal and spatial deviations from baseline geochemical conditions. This information would contribute to the volcanic monitoring efforts, of the UWI Seismic Research Center, on Dominica of a potential monitor for volcanic unrest. Additionally, water samples were also collected from meteoric streams to continue a three-year long monitoring project determining what controls chemical/isotopic variation, and analyzing the potential lasting effects of severe tropical storms (i.e. Tropical Storm Erika, August 2015), which frequently trigger mass wasting events. With updated gas and water chemistry and isotopic data for the period 2014 to 2017, it was possible to re-evaluate the characteristics of these systems, which were last reported in 2011.

Jackie Buskop (Wesleyan University) studied volcanic gasses from multiple geothermal areas. Baseline monitoring of hydrothermal gases of Dominica for the period $2000-2006$ show compositions typical of those found in arc-type settings, with $\mathrm{N}_{2}$ excess and low amounts of He and Ar (Joseph et al., 2011). The 2017 study presents new data on sulphur and nitrogen isotopes to evaluate contributions from various source components. Fumaroles appear to reflect a deeper source contribution as compared to thermal waters with differences in acidity, temperature, TDS, $\delta^{18} \mathrm{O}$, and $\delta \mathrm{D}$ observed. Preliminary results show high $\mathrm{CH}_{4} /$ $\mathrm{CO}_{2}$ ratios for gases from Dominica, which are indicative of a significant hydrothermal contribution to these fluids. However, high helium isotope compositions of $6.6-8.3 \mathrm{R} / \mathrm{Ra}$ indicate a clear magmatic origin. This is consistent with the previously established base- 
line gas chemistry of the hydrothermal systems on Dominica. Notably $\delta^{34} \mathrm{~S}$ values of Dominica fits well with other arc volcanic gases, which are heavier than MORB or plume volcanic gases. This is consistent with the subduction of $\delta^{34} \mathrm{~S}$-enriched seawater sulphate and recycling of sulphur through arc volcanoes. The $\delta^{15} \mathrm{~N}$ values for the hydrothermal gases indicate a lack of $\mathrm{N}_{2}$ contributed from the organic sediment component of the subduction plate. This may be explained by its diversion to the overriding crust rather than subduction into the mantle (Elkins et al., 2006; Fischer et al., 2002; Zimmer et al., 2004).

Dexter Kopas (Beloit College) studied water samples collected from meteoric streams to continue a threeyear long monitoring project determining what controls chemical/isotopic variation, and analyzing the potential lasting effects of severe tropical storms (i.e. Tropical Storm Erika, August 2015), which frequently trigger mass wasting events. Over four years from 2014-2017, water chemistry was tested from 56 Dominican streams. This presented an opportunity to obtain a general overview of the major stream geochemistry and stable isotope composition on the island. It also facilitated the investigation of the major environmental controls on stream geochemistry in the tropics, considering multiple and potentially complex interactions among these factors. Major stream geochemistry show that waters sourced by hydrothermal springs are geochemically similar to their hydrothermal source, and generally contain more $\mathrm{SO}_{4}$ and $\mathrm{Cl}$. Isotopically, purely meteoric streams and meteoric streams with a known hydrothermal influence differ significantly $(\alpha=0.05)$. The mean differences are $0.19 \%$ for $\delta^{18} \mathrm{O}$, and $0.46 \%$ for $\delta \mathrm{D}$. Dominica's west coast is slightly more enriched in $\delta^{18} \mathrm{O}$ compared to the east coast, by $\sim 0.15 \%$ o $(\alpha=0.05)$. However, there is no significant difference in $\delta \mathrm{D}$. The results obtained suggest that there is no single dominant environmental influence on Dominican rivers and that environmental influences are multiple and complex. The lack of correlations suggest that neither dominant wind direction nor precipitation amount influence east-west differences in $\delta^{18} \mathrm{O}$. Hydrothermal sites are a significant influence on stream ion chemistry, which may be dependent on the relative amounts and type of discharge compared to that of the stream water.
Mazi Mathias-Onyeali (University of Colorado) analyzed the waters from geothermal areas, comparing data from published work (Joseph et al., 2011) and ongoing studies since 2014 (Metzger et al., 2015; Metzger et al., 2016; DeFranco et al., 2016). Recent changes in chemistry of the waters have indicated that while the origin of the hydrothermal systems are still dominantly meteoric $\left(\delta^{18} \mathrm{O}=-3\right.$ to $8 \%$ and $\delta \mathrm{D}=$ -5 to $18 \%$ ), surface evaporation effects and variable amounts of mixing with shallow ground waters play an important role. The general composition of the waters for most of the hydrothermal systems studied indicate no significant changes, with the exception of the Boiling Lake, which experienced a draining event in November 2016 which lasted for 6 weeks. Decreases in temperature, $\mathrm{pH}, \mathrm{Na}, \mathrm{K}$, and $\mathrm{Cl}$ were seen post draining, while $\mathrm{SO}_{4}$ remained relatively low (66 ppm), but showed a small increase. The chemistry of the Boiling Lake appears to show significant changes in response to changes in the groundwater system.

\section{Geomorphology (Schmidt)}

Stochastic processes, such as landslides and large tropical storms, are known to be a major driving factor in setting erosion rates over geologic timescales (Kirchner et al., 2001). However, the effects of individual events are difficult to quantify, in part because there are rarely data available from before the event. In addition, tropical environments are typically underrepresented in geomorphic studies compared to temperate and polar locations (Portenga and Bierman, 2011). The geomorphology part of this Frontier project is focused on documenting geomorphic effects of landslides and generally quantifying controls on erosion for Dominica, thus expanding studies of Caribbean erosion from one watershed in Puerto Rico (Brown et al., 1995; Riebe et al., 2003) to also include 20 watersheds on Dominica. Prior work on geomorphology in Dominica has been limited to studies of landslides and debris flows (Degraff et al., 2010; Rouse, 1990), soils (Reading, 1991; Rouse et al., 1986), and chemical weathering (Goldsmith et al., 2010; Rad et al., 2013), but we are unaware of any prior work using detrital sediments to characterize basin-average erosional processes. 
Measuring sediment movement across the landscape - where it comes from, where it is stored, and where it ends up - is fundamental to the study of Earth surface processes. However, until recently, quantifying rates of sediment production, storage, and delivery to channels from hillslopes were difficult, if not impossible, tasks. Doing so required unique situations where one could assume that single measurements of sediment movement were representative of longer time frames. What was needed was a system to trace sediment movement over longer periods of time.

Over the past 20 years, isotopic analysis has opened new ways of quantifying the amount and source of sediment moving over the landscape and through river systems over time scales ranging from tens to millions of years (Stokes and Walling, 2003). In this project we are analyzing four fallout radionuclides: ${ }^{137} \mathrm{Cs},{ }^{210} \mathrm{~Pb}$, ${ }^{7} \mathrm{Be}$, and ${ }^{10} \mathrm{Be}$ in detrital sediments (Figure 2). We are also using $x$-ray fluorescence, $x$-ray diffraction, and concentration of acid-extractable grain coatings as additional proxies of erosional depth and degree of sediment weathering. Students used these chemical measurements of sediment in conjunction with basin analyses in GIS (including slope, rainfall, number and size of landslides, and land use) to characterize spatial patterns of erosion on Dominica over short and long timescales. The four geomorphology student projects each focus on a different piece of the puzzle of understanding erosion on Dominica (Fig. 3).

Marcus Hill (Oberlin College) studied the effects of large storms on landslides and channel geomorphology. He (and other Keck students) mapped landslides on Dominica before and after Tropical Storm Erika and Hurricane Maria. He also used photos he took in the field and those previously taken by PI Frey and her students to complete a repeat photography project. These photos include photos taken before and after both Tropical Storm Erika and Hurricane Maria. Changes observed due to Hurricane Maria included widening and narrowing channels, aggradation and incision, and both deposition and erosion of sediment. Some channels had no noticeable differences in photos whereas others were unrecognizable in the field even when we knew for certain that we were at the exact same spot we sampled just a few months before. In short, there

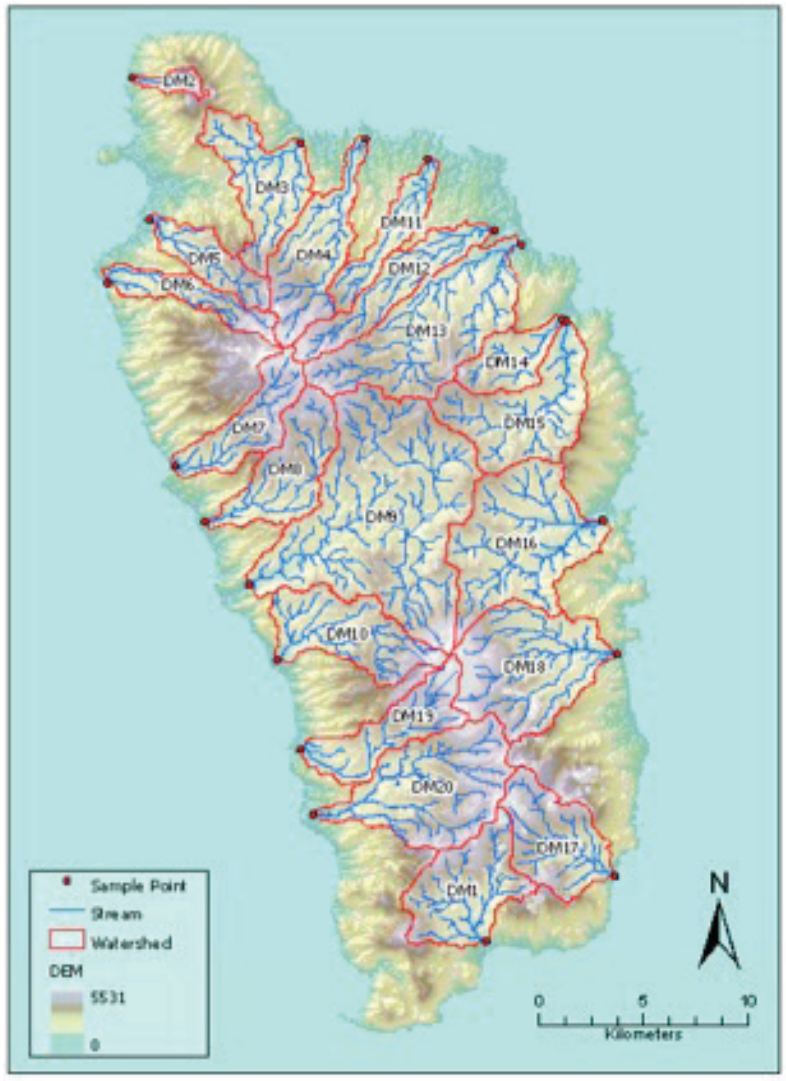

Figure 3. DEM created in GIS depicting the watersheds and major river systems in Dominica.

were no systematic changes he detected across the island. However, he found that changes were typically greater on the west side of the island than the east side. In addition, he observed significant transport of very large boulders into and out of sampling sites, suggesting that the debris flows triggered by Hurricane Maria had extremely high power to move sediment.

Cole Jimerson (College of Wooster) used previously reported ignimbrite ages (Frey et al., 2015) to calculate incision rates by rivers into the ignimbrite deposits and combined this with an analysis of basin-average parameters such as slope, rainfall, and landslide frequency to understand what best controls fluvial incision into ignimbrites. Cole found that incision rates are highest for younger ignimbrites (up to $\sim 6 \mathrm{~mm} / \mathrm{yr}$ for ignimbrites $<25 \mathrm{ka}$ ) and that rates sharply drop to $<1 \mathrm{~mm} / \mathrm{yr}$ for ignimbrites more than $80 \mathrm{ka}$. Rivers incising into younger ignimbrites also tended to have steeper channels (especially through the ignimbrites) and multiple knickpoints along the longitudinal profile. Channels incised into older ignimbrites are inferred to have incised completely 
through the ignimbrite and to be eroding into lava or block and ash flows. These channels have less steep channels without knickpoints. Incision rates correlate best with normalized channel steepness, a measure of channel steepness that is scaled for upstream area. Combined with millennial timescale erosion rates (which are in process but not completed in time for this volume), this could provide a unique comparison of incision to basin-average erosion rates.

Haley Talbot-Wendlandt (Ohio Wesleyan University) analyzed the composition of detrital sediments (measured with XRF and XRD), the concentration of ${ }^{7} \mathrm{Be}$ in the sediment, and the activity of ${ }^{137} \mathrm{Cs}$ and ${ }^{210} \mathrm{~Pb}$ in the sediment. Haley found that the XRD spectra of sediment is similar for all sites sampled, suggesting that all rivers are sourcing similarly weathered sediments. The XRF data vary more across the island and suggest that the composition of fine-grained sediments $(<63 \mu \mathrm{m})$ has more information about the source of sediments than the composition of coarse grained sediments $(250-850 \mu \mathrm{m})$. Haley also analyzed the location of landslides on the island due to Tropical Storm Erika and Hurricane Maria in relation to landslide hazard maps for the island. She found that the landslide hazard maps were largely accurate with most landslides happening in high hazard locations.

Kira Tomenchok (Washington \& Lee University) measured the concentration of acid-extractable grain coatings using an ICP-OES and is comparing the concentration of grain coatings to the concentration of fallout ${ }^{10} \mathrm{Be}$ in detrital samples. Her analysis of the concentration of grain coatings and ${ }^{10} \mathrm{Be}$ in detrital sediments indicate the depth at which material was sourced from in the upstream watershed over long timescales (Greene, 2016) and may correlate with landslide frequency in the upstream watershed.

\section{ACKNOWLEDGEMENTS}

This material is based upon work supported by the Keck Geology Consortium and the National Science Foundation Grant No. 1659322 and permitted by the Dominican Ministry of Forestry. Special thanks to Matthew Manon (Union College) for guiding the SEM, ICP-MS, IC, XRD, and p-XRF analyses at Union College. We also owe a huge debt to Bill Neubeck (Union College), who tuned around $~ 50$ thin- sections and $\sim 20$ grain mounts in less than a week, and Deb Klein (Union College) who assisted with logistics on campus. We are grateful to Nancy Osler and the staff at the Arcbold Tropical Research Center at the Springfield Estate in Dominica who provided us with great food and a place to stay in the field. We'd also like to acknowledge the analytical facilities and personnel at Union College (IRMS lab), UC Davis (electron microprobe facility), UVM $\left({ }^{10} \mathrm{Be}\right.$ extraction), LLNL ( ${ }^{10} \mathrm{Be}$ analyses), and INGV (gas analyses). Thank you to Karl Wirth (Macalaster) who spent some time with us in the field and Cam Davidson (Carleton) who supported us at AGU. Also a special thanks to all of the home advisors who helped guide the project during the academic year: Sue Swanson (Beloit), Kristen Nicolaysen (Whitman), Steve Dunn (Mt. Holyoke), Cam Davidson (Carleton), Karl Wirth (Macalster), Joan Fryxell (Cal State San Bernadino), Joop Varekamp and Tim Ku (Wesleyan), Ron Abbot (U of Colorado), Dave Harbor (Washington \& Lee), Meagan Pollack (College of Wooster), and Bart Martin (Ohio Wesleyan). We would also like to acknowledge the hospitality and strength of the people of Dominica; their tropical paradise was devastated by Hurricane Maria two months after our project. In the face of such adversity, the Dominicans will be resilient and adapt to their ever-changing landscape.

\section{REFERENCES}

Annen, C., Blundy, J.D. and Sparks, R.S.J. (2006) The genesis of intermediate and silicic magmas in deep crustal hot zones. Journal of Petrology 47: 505-539.

Arculus, R.J., Wills, K.J.A. (1980) The petrology of plutonic blocks and inclusions from the Lesser Antilles Arc. Journal of Petrology 21: 743-799.

Bellon H (1989) Reconnaissance chronologique des deux premieres phases d'activite volcanique en Dominique (Petites Antilles). CR Acad Sci Paris 306:1487-1492.

Belousova, E.A., Griffin, W.L., O’Reilly, S.Y., Fisher, N.I. (2002) Apatite as an indicator mineral for mineral exploration: trace element compositions and their relationship to host Rock. Journal of Geochemical Exploration 76:45-69. 
Brown, E.T., Stallard, R.F., Larsen, M.C., Raisbeck, G.M. and Yiou, F. (1995) Denudation rates determined from the accumulation of in-situ produced ${ }^{10} \mathrm{Be}$ in the Luquillo Experimental Forest, Puerto Rico. Earth and Planetary Science Letters 129, 193-202.

Carey, S.N., Sigurdsson, H. (1980) The Roseau ash: deep-sea tephra deposits from a major eruption on Dominica, Lesser Antilles arc. Journal of Volcanology and Geothermal Research 7: 67-86.

DeFranco, K.*, Frey, H.M. and Manon, M.R.F. (2016) Establishing island-wide water characterization in a volcano-hydrothermal system in Dominica, Lesser Antilles. Northeastern section Geological Society of America Abstracts with Programs. Vol. 48, No. 2.

Degraff, J.V., James, A. and Breheny, P. (2010) The formation and persistence of the Matthieu landslide-dam lake, Dominica, WI. Environmental \& Engineering Geoscience 16, 73-89.

Demange J, Leborne H, Traineau H, Westercamp D (1985) Histoire volcano-structurale de la Region sud de la Dominique. Bureau de Recherches Geologiques et Minieres, Institut Mixte de Recherches Geothermiques, Rapport 85 SGN 068 IRG-GTH: 1-114.

DeMets, C., Jansma, P.E., Mattioli, G.S., Dixon, T.H., Farina, F., Bilham, R., Calais, E., Mann, P. (2000) GPS geodetic constraints on Caribbean-North American plate motion. Geophysical Research Letters 27: 437-440.

Elkins, L. J., T. P. Fischer, D. R. Hilton, Z. D. Sharp, S. McKnight, and J. Walker (2006) Tracing nitrogen in volcanic and geothermal volatiles from the Nicaraguan volcanic front. Geochimica et Cosmochimica Acta 70: 5215-5235.

Fischer, T.P., Hildon, D.R., Zimmer, M.M., Shaw, A.M., Sharp, Z.D., Walker, J.A. (2002) Subduction and recycling of nitrogen along the Central American Margin. Science 297:

1154-1157.

Frey, H., Manon, M. and Brehm, S. (2015)

Fingerprinting young ignimbrites in Dominica (Lesser Antilles): Constraints from bulk REEs, apatite chemistry, and U-Th zircon chronology, AGU Fall Meeting Abstracts.
Frey, H.M. and Lange, R.A. (2011) Petrologic complexity in andesites and dacites from the Tequila volcanic field, Mexico: Resolving the effects of degassing vs. magma mixing: Contributions to Mineralogy and Petrology 162: 415-445.

Ghiorso, M.S., and Evans, B.W. (2008). Thermodynamics of rhombahedral oxide solid solutions and a revision of the Fe-Ti twooxide geothermometer and oxygen-barometer. American Journal of Science, 308: 957-1039.

Goldsmith, S.T., Carey, A.E., Johnson, B.M., Welch, S.E., Lyons, W.B., McDowell, W.H. and Pigott, J.S. (2010) Stream Geochemistry, Chemical Weathering and $\mathrm{CO}_{2}$ Consumption Potential of Andesitic Terrains, Dominica, Lesser Antilles. Geochimica Et Cosmochimica Acta 74.1: 85-103.

Greene, E.S. (2016) Comparing meteoric ${ }^{10} \mathrm{Be}$, in situ ${ }^{10} \mathrm{Be}$, and native ${ }^{9} \mathrm{Be}$ across a diverse set of watersheds, Geology. University of Vermont, Burlington, VT, p. 118.

Gurenko, A.A., Trumbull, R.B., Thomas, R., Lindsay, J.M. (2005) A melt inclusion record of volatiles, trace elements and Li-B isotope variations in a single magma system from the Plat Pays volcanic complex, Dominica, Lesser Antilles. Journal of Petrology 46: 2495-2526.

Halama, R., Boudin, G., Villemant, B., Joron, J.L., Le Fraint, A., Komorowski, J.C. (2006) Preeruptive crystallization conditions of mafic and silicic magmas at the Plat Pays volcanic complex, Dominica (Lesser Antilles). Journal of Volcanology and Geothermal Research 153: 200-220.

Howe, T.M., Lindsay, J.M., and Shane, P. (2105a) Eruption of young andesitic-dacitic magmatic systems beneath Dominica, Lesser Antilles: Journal of Volcanology and Geothermal Research 297:9-88.

Howe, T.M., Schmitt, A.K., Lindsay, J.M., Shane, P., and Stockli, D.F (2015b) Time scales of intraoceanic arc magmatism from combined U-Th and (U-Th)/He zircon geochronology of Dominica, Lesser Antilles: Geochemistry, Geophysics, Geosystems 16:347-365. 
Howe, T.M., Lindsay, J.M., Shane, P., Schmitt, A.K., and Stockli, D.F. (2014) Re-evaluation of the Roseau Tuff eruptive sequence and other Ignimbrites in Dominica, Lesser Antilles. Journal of Quaternary Science 29(6): 531-546.

Joseph, E.P., Fournier, N., Lindsay, J.M., Fischer, T.B. (2011) Gas and water geochemistry of geothermal systems in Dominica, Lesser Antilles island Arc, Journal of Volcanology and Geothermal Research. 206:1-14.

Joseph, E.P., Fournier, N., Lindsay, J.M., Robertson, R., and Beckles, D. (2013) Chemical and isotopic characteristics of geothermal fluids from Sulphur Springs, Saint Lucia. Journal of Volcanology and Geothermal Research 254: 23-36.

Kirchner, J.W., Finkel, R.C., Riebe, C.S., Granger, D.E., Clayton, J.L., King, J.G. and Megahan, W.F. (2001) Mountain erosion over 10 yr, 10 k.y., and 10 m.y. time scales. Geology 29, 591-594.

Lindsay, J.M., Stasiuk, M.V., Shepherd, J.B. (2003) Geological history and potential hazards of the late- Pleistocene to Recent Plat Pays volcanic complex, Dominica, Lesser Antilles, Bulletin of Volcanology 65: 201-220.

Lindsay, J. M., Trumball, R.B., Siebel, W. (2005a)

Geochemistry and petrogenesis of Late

Pleistocene to recent volcanism in southern

Dominica, Lesser Antilles. Journal of Volcanology and Geothermal Research 148: 253-294.

Lindsay, J.M., Smith, A.L., Roobol, M.J., and Stasiuk, M.V. (2005b) Dominica: Volcanic Hazards of the Lesser Antilles. Seismic Research Unit, The University of the West Indies, Trinidad and Tobago.

Metzger, T.*, Frey, H.M., Manon, M.R.F., and DeFranco, K.* (2016) Island-wide isotopic analysis of meteoric and hydrothermal waters in Dominica, Lesser Antilles. Geological Society of America Abstracts with Programs. Vol. 48, No. 7. Metzger, T.*, Frey, H.M., and Manon, M.R.F. (2015)

Water geochemistry analysis of streams and hydrothermal waters in Dominica, Lesser Antilles. Northeastern section Geological Society of America Abstracts with Programs, Vol. 47.
Monjaret, M.C. (1985) Contribution a l'etude de l'arc des Petites Antilles. Le Volcanisme de la Dominique. Donnees chronologiques, mineralogiques et geochimiques. Unpublished Thesis, Universite de Bretagne Occidentale, 1-77. Portenga, E.W. and Bierman, P. (2011) Understanding Earth's eroding surface with 10Be. GSA Today 21, 4-10.

Rad, S., Rivé, K., Vittecoq, B., Cerdan, O. and Allègre, C.J. (2013) Chemical weathering and erosion rates in the Lesser Antilles: An overview in Guadeloupe, Martinique and Dominica. Journal of South American Earth Sciences 45, 331-344.

Reading, A.J. (1991) Stability of tropical residual soils from Dominica, West Indies. Eng Geol 31, 27-44.

Riebe, C.S., Kirchner, J.W. and Finkel, R.C. (2003) Long-term rates of chemical weathering and physical erosion from cosmogenic nuclides and geochemical mass balance. Geochim Cosmochim Ac 67, 4411-4427.

Rivé, K., Gaillardet, J., Agrinier, P. and Rad, S. (2013) Carbon Isotopes in the Rivers from the Lesser Antilles: Origin of the Carbonic Acid Consumed by Weathering Reactions in the Lesser Antilles. Earth Surface Processes and Landforms 38: 1020-035.

Roobol MJ, Wright JV, Smith AL (1983) Calderas or gravity-slide structures in the Lesser Antilles island arc? Journal of Volcanology and Geothermal Research 19: 121-134.

Rouse, C. (1990) The mechanics of small tropical flowslides in Dominica, West Indies. Eng Geol 29, 227-239.

Rouse, W., Reading, A. and Walsh, R. (1986) Volcanic soil properties in Dominica, West Indies. Eng Geol 23, 1-28.

Ruzie, L., Aubaud, C., Morira, M., Agrinier, P., Dessert, C., Greau, C., and Crispi, O. (2013) Carbon and helium isotopes in thermal springs of La Soufriere volcano (Guadeloupe, Lesser Antilles): Implications for volcano monitoring. Chemical Geology 359: 70-80.

Sigurdsson, H. (1972) Partly-welded pyroclastic flow deposits in Dominica, Lesser Antilles, Bulletin of Volcanology 36: 148-163. 
Smith, A.L., Roobol, M.J., Mattioli, G.S., Fryxell, J.E., Daly, G.E., Fernandez, L.A. (2013) The Volcanic Geology of the Mid-Arc Island of Dominica, Lesser Antilles - The Surface Expression of an Island-Arc Batholith. The Geological Society of America, Special Paper, 496.

Sparks, R.S.J., Sigurdsson, H., and Carey, S.N. (1980) The entrance of pyroclastic flows into the sea I. Oceanographic and geologic evidence from Dominica, Lesser Antilles. Journal of Volcanology and Geothermal Research 7(1): 87-96.

Stokes, S. and Walling, D.E. (2003) Radiogenic and isotopic methods for direct dating of fluvial sediments, in: Kondolf, G.M., Piegay, H. (Eds.), Tools in Fluvial Geomorphology. John Wiley and Sons, West Sussex, pp. 233-267.

Wadge, G., and Shephard, J.B. (1984) Segmentation of the Lesser Antilles subduction zone. Earth and Planetary Science Letters 71; 297-304.

Waters, L.E., and Lange, R.A. (2015). An updated calibration of the plagioclase-liquid hygrometerthermometer applicable to basalts through rhyolites. American Mineralogist, 100: 2172-2184.

Wills K (1974) The Geological History of Southern Dominica and Plutonic Nodules from the Lesser Antilles. PhD Thesis, University of Durham.

Zimmer, Mindy M., Tobias P. Fischer, David R. Hilton, Guillermo E. Alvarado, Zachary D. Sharp, and James A. Walker (2004) Nitrogen systematics and gas fluxes of subduction zones: insights from Costa Rica arc volatiles. Geochemistry, Geophysics, Geosystems 5: Q05J11, doi:10.1029/2003GC000651. 